\title{
A nemzeti park igazgatóságok 2000-2015 közötti költségvetésének értékelése az alapfeladataik tükrében
}

\author{
Kovács Eszter \\ Szent István Egyetem, Természetvédelmi és Tájgazdálkodási Intézet, \\ 2100 Gödöllö, Páter Károly u. 1. \\ e-mail:kovacs.eszter@mkk.szie.hu
}

\begin{abstract}
Összefoglaló: A nemzeti park igazgatóságok működésének stabilitása szempontjából fontos, hogy az alapfeladataik ellátásához folyamatosan rendelkezésre álljanak a szükséges források. Ebben a cikkben azt vizsgáljuk meg, hogy az igazgatóságok alapfeladatai hogyan változtak 2000-től 2015-ig, és azok mértékének megfelelően alakult-e a személyi állomány és a források nagysága. Az elemzések alapján megállapíthatjuk, hogy a vizsgált időszakban, különösen az uniós csatlakozást követően jelentősen növekedett az ellátandó feladatok köre és mennyisége is. A megnövekedett feladatokhoz ugyan növekvő létszám is párosult, de ez a közfoglalkoztatottak számának és arányának növekedését jelentette leginkább, míg a nem közfoglalkoztatott állomány, azon belül a természetvédelmi őrök létszáma alig emelkedett az időszak egészét tekintve. Az igazgatóságok költségvetése jelentősen, mintegy 5-szörösére emelkedett a vizsgált időszakban, de a növekedés legnagyobb részben az átvett pénzeszközöknek, támogatásértékü bevételeknek, azon belül az uniós társfinanszírozású pályázati forrásoknak volt köszönhetö. A közvetlen állami támogatás ezzel szemben alig növekedett, s 2015-ben nem érte el nominális értékben a 2002. évi szintet sem. Ez növelte az igazgatóságok kiszolgáltatottságát a külső forrásoknak. amelyek nagy része kötött felhasználású volt, így a bővülö források ellenére maradhattak alulfinanszírozott alapfeladatok. Az eredmények alapján az alapfeladatok finanszírozási igényének pontos felmérése, az állami közvetlen támogatás és a stabil, nem közfoglalkoztatott létszám jelentős növelése javasolt. Az elemzéseket további kutatásokkal lehet árnyalni és nemzetközi kontextusba helyezni.
\end{abstract}

Kulcsszavak: nemzeti park igazgatóságok, költségvetés, finanszírozás, hazai és nemzetközi pénzügyi források

\section{Bevezetés}

A nemzeti park igazgatóságok (NPI-k) összetett tevékenységüknél fogva a hazai természetvédelem kiemelkedően fontos szereplőinek tekinthetők, ezért lényeges, hogy az alapfeladataik ellátására a finanszírozásuk hosszú távon, folyamatosan biztosítva legyen. Jelen rövid áttekintéssel az a célom, hogy bemutassam, hogyan alakult a költségvetésük, illetve a finanszírozási struktúrájuk az ezredfordulótól 
2015-ig, változó feladatkörük és bővülő alapfeladataik mellett. Ehhez először a vonatkozó jogszabályok és a rendelkezésre álló adatok alapján megvizsgálom, hogy feladatkörük és a feladatok mennyisége hogyan változott a vizsgált időszak alatt, $\mathrm{s}$ ennek tükrében tekintek rá a létszámuk és a költségvetésük alakulására. A költségvetésen belül a kiadási és a bevételi oldalt is megvizsgálom arra keresve a választ, hogy elegendő és megfelelő struktúrájú volt-e az alapfeladatok végzéséhez rendelkezésre álló forrás.

\section{Módszerek}

A NPI-k költségvetésének vizsgálatához elsősorban az ún. zárszámadási törvényeket (irodalomjegyzékben nevesítve) és kapcsolódó fejezeti (minisztériumi) indoklásokat vettem alapul (http1), amelyek az adott évre vonatkozó költségvetési törvény végrehajtását mutatják be, fejezetekre lebontott szöveges és számszaki indoklással, illetve részletes létszámtáblával együtt. A zárszámadási törvényekben és kiegészítő dokumentumaikban szereplő adatokat kiegészítettem hazai adatbázisokból származó, a Földmüvelésügyi Minisztériumtól (FM) és a Magyar Államkincstártól (MÁK) kapott, valamint egyéb hozzáférhető forrásokból származó adatokkal. Az alapfeladatok meghatározásához a vonatkozó jogszabályokat használtam fel.

Elöljáróban már most érdemes jelezni, hogy változó volt az egyes évekre rendelkezésre álló adatok és információk köre. A zárszámadási törvényekhez kapcsolódó fejezeti szöveges és számszaki indoklások, illetve részletes létszámtáblázatok a 2000. és 2002. évre nem álltak rendelkezésre. Egyes adatok azonban a következő évi szöveges beszámolók és kiegészítő táblázatok adataiból rekonstruálhatóak voltak. Az NPI-k általában külön címet alkotnak a természetvédelemért felelős minisztérium költségvetésében, de 2005-ben és 2006-ban a környezetvédelmi, természetvédelmi és vízügyi területi szerveket egy cím alatt jelenítették meg, így az NPI-kre vonatkozóan nem állt rendelkezésre a teljes részletezettségú költségvetés. Néhány adatot azonban a 2006. évi szöveges beszámoló tartalmazott mindkét évre, amelyet fel tudtam használni az elemzéseknél. 2014-től változott a részletes számszaki indoklás szerkezete, ami szintén nehezítette az egységes adatkezelést. Az egyes összesítő diagramoknál a korlátokat jelezni fogom.

A feladatok jellegének és mennyiségének változásához az alábbiakat vizsgáltam elsősorban:

- az igazgatóságok feladatkörében történő változások

- $\quad$ az országosan védett természeti területek és Natura 2000 területek kiterjedésében történt változások 
- a vagyonkezelt terület nagyságában történő változások

- a saját vagyonkezelésben lévő állatállomány nagyságának változása

- a bemutató infrastruktúra (látogatóközpontok, bemutatóhelyek, erdei iskolák) bővülése

A forrásokkal való ellátottság megállapítására az alábbiakat értékeltem:

- a létszám, azon belül a közfoglalkoztatottak és a természetvédelmi őri létszám változásai

- $\quad$ az összköltségvetés nagyságának alakulása

- a kiadási oldalon a múködési (személyi és dologi kiadások) és felhalmozási költségvetés nagyságának változása

- a források összetételében (közvetlen állami támogatás, intézményi bevétel és átvett pénzeszközök) történt változások

A költségvetési összegeket az elemzésben nominális értékben adtam meg, vagyis nem korrigáltam az éves infláció mértékével. Ennek egyrészt az az oka, hogy az infláció számításához alkalmazott fogyasztói árindex torzította volna az eredményeket, ugyanis az igazgatóságok költségvetése beruházási elemeket is tartalmaz, amelyek árváltozásainak megragadására a termelői és ingatlan árindexek alkalmasabbak. Másrészt a beruházásokat, felhalmozási tételeket külön kezelő pontosabb számítás elvégzéséhez a KSH adatok egy része nem állt rendelkezésre a teljes vizsgált időszakra, az NPI-k összköltségvetésének tekintetében pedig sem a kiadási, sem a forrás oldal nem volt kellő részletezettségü1. Ahol lehetett, az éves adatok felhasználásával készítettem összefoglaló táblázatokat és diagramokat, de az elemzéseknél a főbb trendekre voltam kíváncsi, ezért az egyes években tapasztalható kisebb ingadozások értékelésére nem tértem ki. Összesített adatokkal dolgoztam, így nem volt célom az egyes igazgatóságok közötti különbségek feltárása. Tisztában vagyok azzal, hogy az igazgatóságok adottságaiban, működésében, költségvetésük kiadási és bevételi oldalának összetételében jelentős eltérések mutatkoznak, de ezek részletes értékeléséhez az igazgatósági költségvetési beszámolók elemzésére lenne szükség.

1: A nagyságrend érzékeltetésére jelzem, hogy a KSH által közzétett fogyasztói árindex adatok alapján a 2000. évi nominális összegeket 1,93-es, a 2004. évi nominális összegeket 1,5-es szorzóval lehet a 2015. évre átszámolni (saját számítás http2 alapján). 


\section{Eredmények}

A nemzeti park igazgatóságok feladatkörének változása a vizsgált időszakban A nemzeti park igazgatóságoknak már 2000-ben is sok alapfeladatot kellett ellátniuk, hiszen hatósági, területkezelési, nyilvántartási, monitorozási, környezeti nevelési és ökoturisztikai feladataik egyaránt voltak, amint azt az alábbi listából is láthatjuk (211/1997 (XI. 26) Korm. rendelet alapján):

- természetvédelmi első fokú hatósági jogkör gyakorlása

- természetvédelmi őrszolgálat müködtetése és az önkormányzati természetvédelmi őrszolgálat segítése

- védetté nyilvánítások előkészítése

- a természet és élővilág állapotának figyelemmel kísérése, természetvédelmi területi monitoring és információs rendszer müködtetése

- egyedi tájértékek nyilvántartása

- $\quad$ vagyonkezelési feladatok ellátása (az NPI-k vagyonkezelésében lévő védett természeti területek és értékek, természetvédelmi bemutató, oktatási célú és idegenforgalmi létesítmények tekintetében)

- $\quad$ természetvédelmi kezelési ${ }^{2}$ feladatok (védett természeti területek és értékek) ellátása

- $\quad$ tájvédelmi feladatok ellátása

- területfejlesztési koncepciók, programok, területrendezési tervek véleményezése, egyeztetési eljárásában való közremüködés

- $\quad$ közremüködés az erdővagyon védelmi tevékenységben

- közremüködés a nem védett természetes növény- és állatvilág védelmében

- közremüködés a természetvédelmi kutatási, oktatási, nevelési és ismeretterjesztési tevékenységekben

- $\quad$ közremüködés a Központi Környezetvédelmi Alap kezelésével kapcsolatos feladatokban

- $\quad$ az települési önkormányzatok természetvédelmi munkájának segítése

- $\quad$ együttmüködés számos érintett szervezettel, szervvel, természetes személylyel

A vizsgált időszakban az uniós csatlakozást követően jelentkezett a legnagyobb változás az alapfeladatok körét tekintve, amelyet az 1. táblázatban láthatunk.

A táblázatban szereplö alapfeladatokon túl, jogszabályban nem nevesített feladatként jelentkezett 2005-től a közmunkaprogrammal (később közfoglalkoztatási programmal) kapcsolatos területi feladatok ellátása. 2010-től, szabályzat

2: A természet védelméről szóló 1996. évi 53. törvény 36. § (2) szerint „természetvédelmi kezelésnek minősül a védett természeti érték, terület felmérését és nyilvántartását, megóvását, örzését, fenntartását, bemutatását, valamint helyreállítását célzó valamennyi tevékenység”. 
1. táblázat. A nemzeti park igazgatóságok alapfeladatainak változása 2000 után (forrás: 341/2004 (XII. 22.) Korm. rendelet alapján saját szerkesztés).

Megj. A kutatási, nyilvántartási és élőhely fenntartási/rehabilitációs feladatokat is külön nevesíti a Korm rendelet, de ezek már korábban is az igazgatóság feladatkörébe tartoztak, csak átfogóbb címszavak alatt szerepeltek. A Környezetvédelmi Alapot később felváltotta a KAC (Környezetvédelmi alap célfeladat fejezeti kezelésủ elöirányzat) majd a Kövice (Környezetvédelmi és vízügyi célelőirányzat), de a kapcsolódó feladat jellege nem változott.

*30/2001. (XII. 28.) KöM rendelet

**2/2002. (I. 23.) KöM-FVM együttes rendelet

\begin{tabular}{|c|c|}
\hline Alapfeladatok csökkenése & Alapfeladatok növekedése \\
\hline $\begin{array}{l}\text { - elsőfokú hatósági jogkör átkerülése a kör- } \\
\text { nyezetvédelmi, természetvédelmi és vízügyi } \\
\text { felügyelöségekhez } \\
\text { - tájvédelmi szakhatósági feladatok átkerülé- } \\
\text { se a felügyelőségekhez }\end{array}$ & $\begin{array}{l}\text { - Natura } 2000 \text { területté nyilvánítási feladatok } \\
\text { ellátása } \\
\text { - } \text { a Natura } 2000 \text { területek és a nemzetközi ter- } \\
\text { mészetvédelmi egyezmény hatálya alá eső } \\
\text { területek és értékek természetvédelmi keze- } \\
\text { lési feladatainak ellátása } \\
\text { - } \text { kezelési tervek készítése (2002-től*) } \\
\text { - barlangok állapotfelvétele } \\
\text { - védett növénytársulások fenntartására, ke- } \\
\text { zelésére vonatkozó terv elökészítése } \\
\text { - } \text { a körzeti erdő- és vadgazdálkodási tervekkel } \\
\text { kapcsolatos feladatok ellátása } \\
\text { - } \text { közremüködés a régészeti örökség védelmé- } \\
\text { vel kapcsolatos örzési feladatok ellátásban } \\
\text { - } \text { közremúködés a természetvédelmi hatósági } \\
\text { és, szakhatósági és tájvédelmi szakhatósági } \\
\text { eljárásokban } \\
\text { - } \text { közremüködés az árvíz- és belvízvédekezés- } \\
\text { sel kapcsolatos feladatok ellátásában } \\
\text { - érzékeny természeti területek létesítésével } \\
\text { és kijelölésével kapcsolatos feladatok ellá- } \\
\text { tása (2002-töl**) } \\
\text { - } \text { közremúködés az agrár-környezetvédelmi } \\
\text { programokkal kapcsolatos feladatok ellátá- } \\
\text { sában (2002-töl**) }\end{array}$ \\
\hline
\end{tabular}

formájában 2012-től új feladatként megjelent a nemzeti parki védjegyrendszer müködtetésével kapcsolatos területi feladatok ellátása is (vidékfejlesztési miniszter NPTF-172/4/2012 utasítása), amelyet szintén nem emel ki az alapfeladatokat tárgyaló jogszabály.

2015-ben új jogszabály jelent meg az igazgatóságok alapfeladatairól (71/2015 (III. 30.) Korm. rendelet), ami a feladatkört a korábbiakhoz képest lényegében nem szükítette, csak az egyéb jogszabályokban meghatározott feladatokat már nem nevesítette.

A fentiek alapján megállapítható, hogy összességében véve a feladatkör jelentős bővülését tapasztalhattuk a vizsgált időszak alatt. Valószínüsíthetően nem 
csökkent lényegesen a hatósági munkához kapcsolódó feladatok mennyisége sem. A hatósági eljárásokhoz szükséges területi ismeretekkel ugyanis az NPI-k rendelkeztek a hatósági jogkör elkerülése után is, emiatt a hatóságok a vizsgált időszak további éveiben is rá voltak utalva az NPI-k szakembereinek állásfoglalásaira, szaktanácsadó munkájára.

A nemzeti park igazgatóságok feladatait jellemzö mennyiségi mutatók (terület, állatállomány, bemutató infrastruktúra)változása a vizsgált idöszakban A védett természeti területek kiterjedése a 2000-es 816 ezer hektárról 2015-re 850 ezer hektár körüli értékre emelkedett, ahogy ezt az. 1. ábra is mutatja. A 2000-

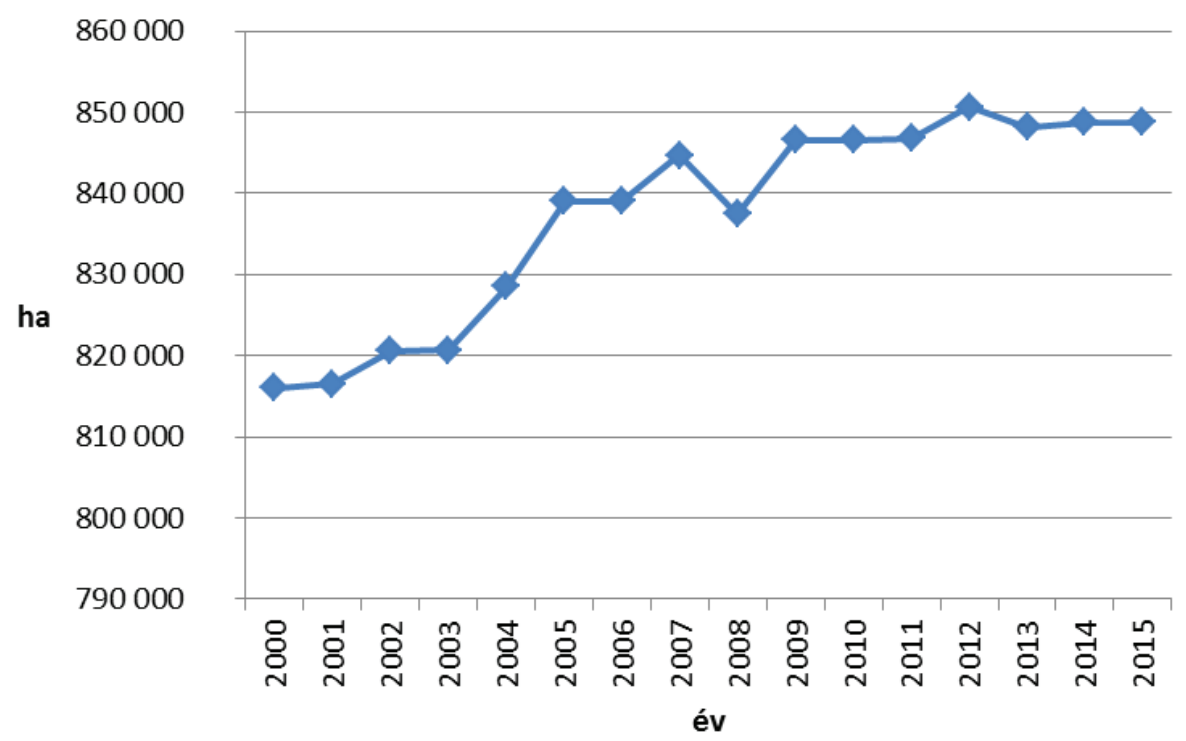

1. ábra. Az országosan védett természeti területek kiterjedésének változása 2000-től 2015-ig (http3 alapján saját szerkesztés). Megj. Az ábrában a 2008. évnél látható csökkenés nem jelent tényleges csökkenést a védett területek kiterjedésében, csak adatpontosítást. A 2008. évtől a nyilvántartási rendszert térinformatikai alapokra helyezték, ami az adatok pontosításával járt.

es évek elején még nagyobb arányú volt a növekedés, míg 2009 után a védetté nyilvánítási folyamat már nagyon lelassult. Ennél sokkal jelentősebb feladatnövekedést jelentett a Natura 2000 területek kijelölése 2004-ben (1,96 millió hektár a csatlakozáskor, 2011-től, a kijelölési folyamat lezárását követően 1,99 millió hektár) (KvVM TKSZÁT 2007, VM TKSZÁT 2011). A védett természeti területekhez képest több mint 1 millió hektár természetvédelmi kezelése lett NPI feladat.

A védett területek mellett a saját vagyonkezelésben, és ezen belül a saját hasznosításban lévő területek kiterjedése és az állatállomány nagysága is utal az igaz- 
gatóság feladatainak nagyságrendjére. A 2. ábra azt mutatja, hogy az NPI-k saját vagyonkezelésében lévő területeinek kiterjedése a 2000-es évek elején a 209 ezer hektár körüli értékröl indult, s először erősebb, majd lassuló növekedéssel, 2015ben megközelítette a 300.000 hektárt. A növekedés 1,4-szeres a 2001. év adatához viszonyítva. A saját hasznosítású területek aránya az időszak egészében 42-56\% között ingadozott, 2015-ben 50\% volt. Az állatállomány kisebb ingadozásokkal, de folyamatosan növekedett a vizsgált időszakban. A 2000-es évek elején nem érte el a 4000 egyedet, 2015-ben pedig megközelítette a 14.000 egyedet (FM

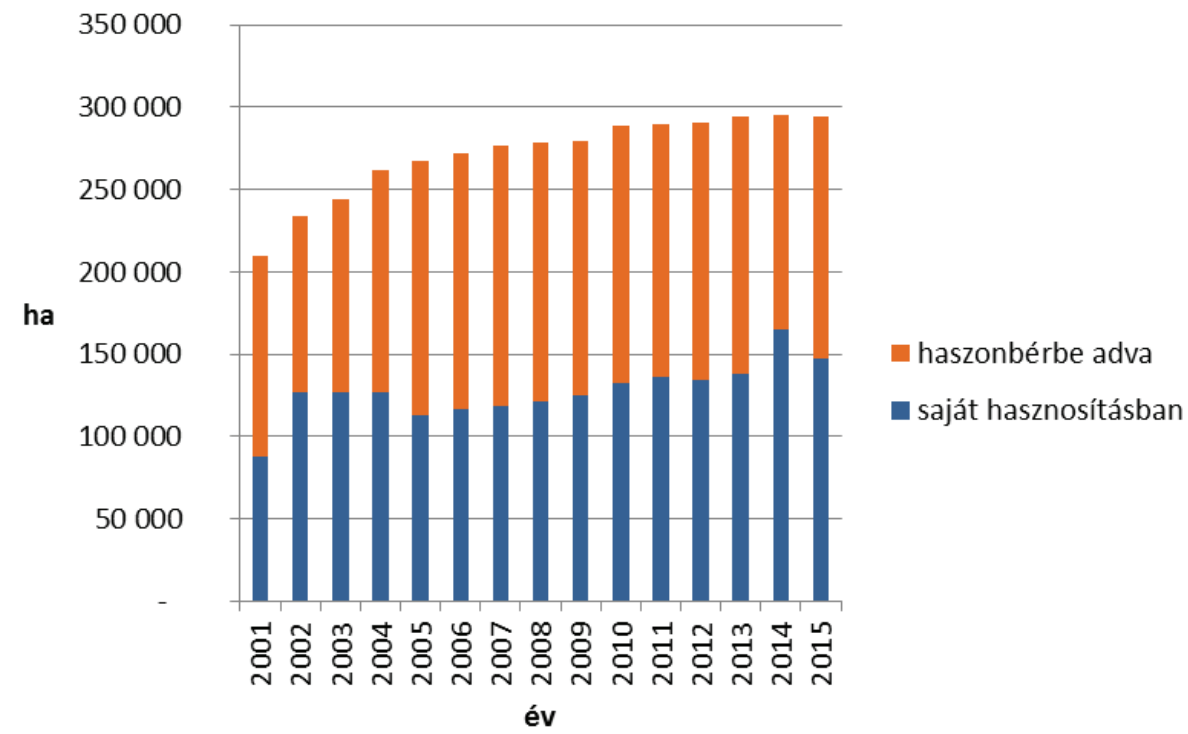

2. ábra. A nemzeti park igazgatóságok vagyonkezelésében lévő területek kiterjedése 2001 és 2015 között saját hasznosítású és haszonbérbe adott területek bontásában (FM 2017. márciusi adatszolgáltatása alapján saját szerkesztés).

adatszolgáltatás 2017), mely közel 3,5-szeres növekedést jelent. Az állatállomány legnagyobb részét a magyar szürke marha, magyar tarka marha, bivaly és ló állomány tette ki, amelynek alakulását részletesen mutatja a 3. ábra. Az időszak elején még a juhállomány, az időszak végén már a szürke marha állomány volt a legjelentősebb. 2015-ben a szürke marha állomány 6413 egyedet, míg a juhállomány 3461 egyedet számlált. A legnagyobb mértékü növekedést (13,6-szeres) a bivaly állományában tapasztalhattuk a vizsgált időszak alatt, amely a 2000. évi 149 egyedről 2015-re 2027 egyedre nőtt. A magyar tarka marha és a ló állománya is 500 egyed alatt maradt az egész időszak alatt. 


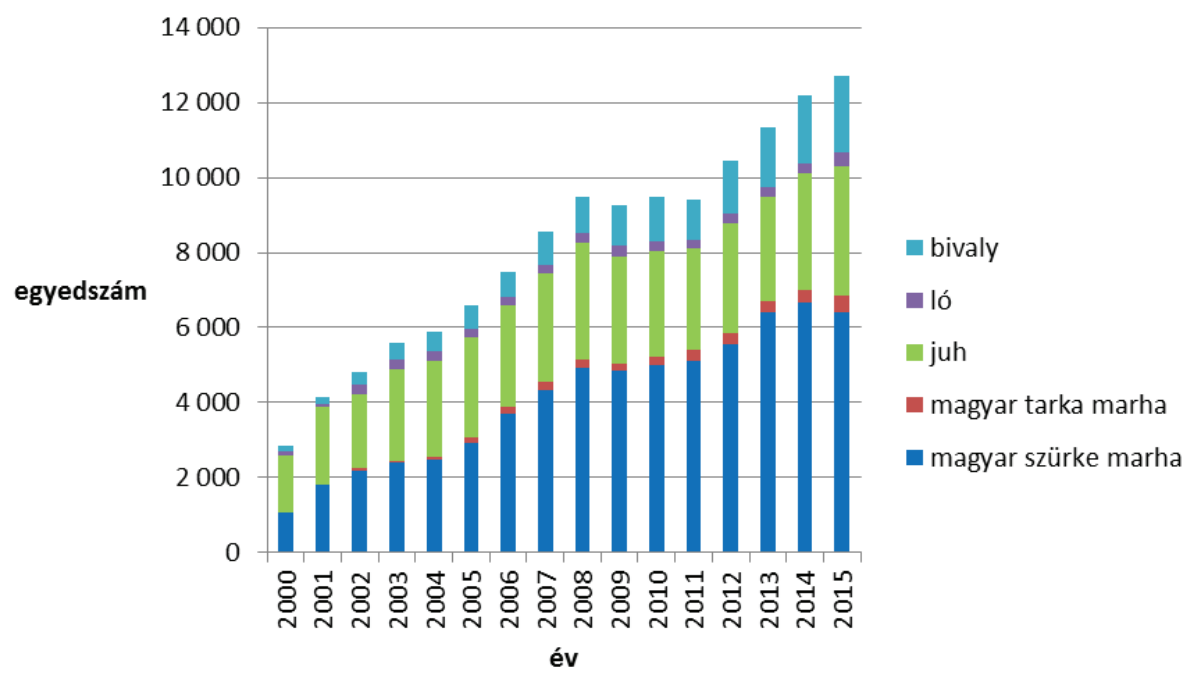

3. ábra. A nemzeti park igazgatóságok állatállományából a legfontosabb fajták egyedszámának alakulása 2000-től 2015-ig (FM 2017. márciusi adatszolgáltatása alapján saját szerkesztés).

Az időszak elejéről nem állnak rendelkezésre pontos adatok az NPI-k által üzemeltetett bemutatóhelyek számára vonatkozóan, ezért a 2. táblázat csak a hivatkozható forrásokból származó 2008-as és 2014-es adatokat tartalmazza. A 2. táblázat mutatja, hogy a két időpont között is jelentős bővülés következett be a bemutató infrastruktúra tekintetében. Ez azt is jelenti, hogy a müködtetés költségei is megnőttek a vizsgált időszak alatt.

2. táblázat. A nemzeti park igazgatóságok bemutatóhelyeinek száma típus szerint 2008-ban és 2014-ben (adatok forrása: Ökoturizmus Fejlesztési Stratégia 2008; Nemzeti Természetvédelmi Alapterv IV. 2015).

\begin{tabular}{|c|c|c|}
\hline Bemutatóhely típusok & $2008(\mathrm{db})$ & $2014(\mathrm{db})$ \\
\hline $\begin{array}{l}\text { fogadó, látogató- és ok- } \\
\text { tatóközpontok }\end{array}$ & 26 & 31 \\
\hline tanösvények & 148 & 169 \\
\hline $\begin{array}{l}\text { idegenforgalom számára } \\
\text { megnyitott barlangok }\end{array}$ & 39 & 42 \\
\hline erdei iskolák & 6 & 14 \\
\hline tájházak & 7 & 7 \\
\hline $\begin{array}{l}\text { arborétumok, növé- } \\
\text { nykertek }\end{array}$ & 3 & 3 \\
\hline egyéb bemutatóhelyek & 39 & 53 \\
\hline Összesen & 268 & 319 \\
\hline
\end{tabular}


A fentiek alapján megállapíthatjuk, hogy a Natura 2000 területek kijelölésével, a vagyonkezelt területek és állatállomány növekedésével, valamint a bemutatási infrastruktúra bővülésével az NPI-k feladatainak mennyisége és forrásigénye is jelentősen növekedett a vizsgált időszak alatt. A következőkben azt nézzük meg, hogy a feladatok bővülését és mennyiségi növekedését követte-e és milyen mértékben a személyi állomány és a rendelkezésre álló források növekedése.

\section{A NPI-k müködésének személyi háttere}

A 4. ábrából láthatjuk, hogy a vizsgált időszak egészét tekintve az összlétszám mintegy 3,1-szeresére növekedett. A nem közhasznú foglalkoztatottak létszámának növekedése 2001-hez képest azonban csak 1,7-szeres, 2004-hez viszonyítva 1,3-szeres, és 2015-ben sem érte el az 1100 föt. Ennek alapján arra következtethetünk, hogy a feladatkör bővülését és a feladatok mennyiségi növekedését nem követte az állandó alkalmazotti létszám növekedése. A közfoglalkoztatottak aránya

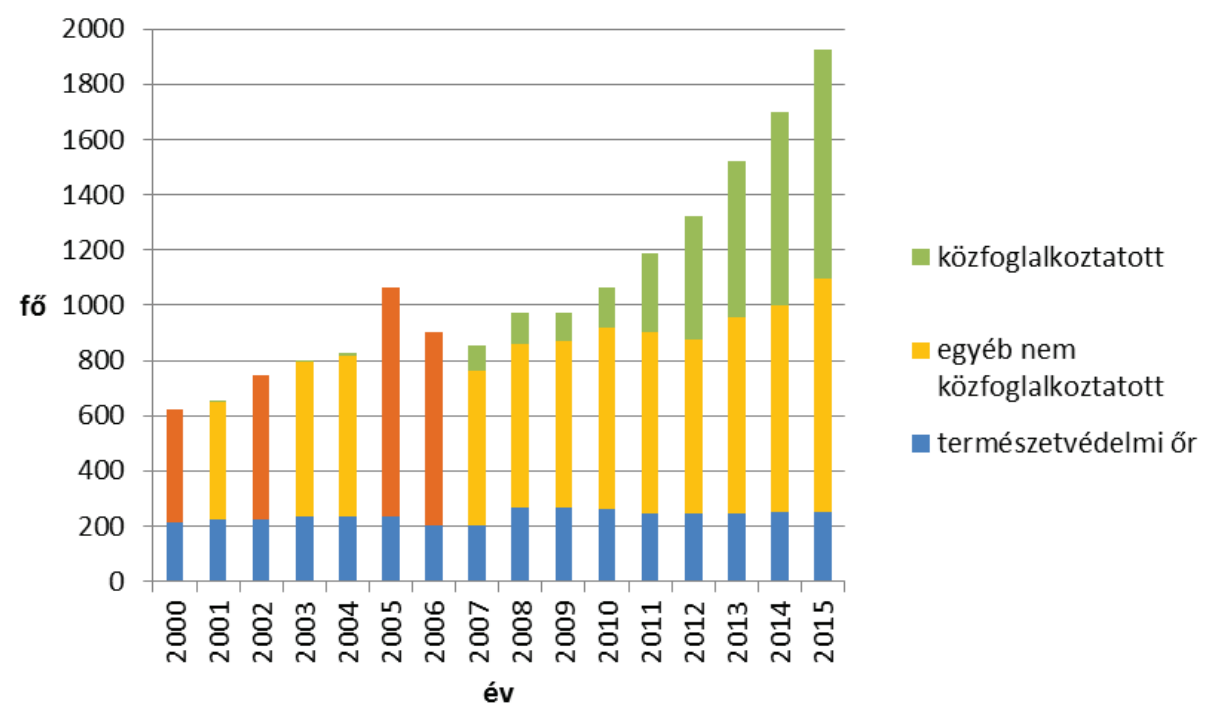

4. ábra. A nemzeti park igazgatóságok létszámának alakulása 2001-től 2015-ig természetvédelmi ör, nem közfoglalkoztatott és közfoglalkoztatott szerinti bontásban (saját számítás és szerkesztés az alábbi forrásokból származó adatok alapján: teljes létszám és a közfoglalkoztatottak létszáma: zárszámadási törvények fejezeti indoklásainak létszám táblázatai, természetvédelmi őri létszám: FM 2017. márciusi adatszolgáltatása). Megj. A 2000., 2002., 2005. és 2006. évre vonatkozóan a rendelkezésre álló fejezeti (minisztériumi) zárszámadási beszámolók és mellékleteik csak összevont létszámadatokat tartalmaztak, amelyből az őrszolgálat létszámának levonásával fennmaradó részt jelzi a narancssárga oszloprész az adott éveknél. A 2000. évi összevont adatot a 2001. évi, a 2002. évi összevont adatot a 2003. évi, a 2005. és 2006. évi összevont adatokat a 2006. évi szöveges beszámolók tartalmazták. 
2001-ben még nem érte el az összes foglalkoztatott 1\%-át, 2007-ben 11\% volt ez az arány, míg 2015-ben már meghaladta a teljes létszám 43\%-át. A természetvédelmi őrök létszáma a 2000-es 213 főről 2015-re 250 főre emelkedett, ami csak 1,2-szeres növekedést jelent. 2000-ben egy örre 4000 hektárnál kevesebb védett természeti terület jutott átlagosan, míg 2004 után a Natura 2000 területek kijelölésével már átlagosan 8000 hektár körüli terület természetvédelmi kezelését kellett egy őrnek ellátnia (2005 és 2015 között ez a szám 7400 és 9700 ha/fö között ingadozott, az őri létszám és a Natura 2000 terület változásával). Ebből az látszik, hogy a feladatok növekedését nem követte az őri létszám szükséges növekedése sem.

A nemzeti park igazgatóságok költségvetésének változása a vizsgált idöszakban Az igazgatóságok költségvetésének elemzésénél a megvalósult költségvetést vesszük alapul a zárszámadási törvények és mellékleteik alapján, s megnézzük a bevétel és a kiadás oldalát is. Fontos megjegyezni, hogy a kiadási és a bevételi oldal számai némileg eltérhetnek egymástól. Ez általában annak köszönhető, hogy az év végén beérkezett összegek kiadási előirányzathoz rendelése és felhasználása átcsúszhat a következő évre. Így az adott évben a bevételi oldalon megjelenik az összeg, de a kiadási oldalon még nem. A következő évben ez maradványként jelentkezik a bevételi oldalon. Jelen tanulmányban a bevételek előző évi maradvánnyal csökkentett értékét vettem alapul az elemzésekhez.

Elöször a kiadási oldal nézzük meg, megkülönbözetve a személyi, a dologi és a felhalmozási/beruházási jellegü kiadásokat. Az 5. ábra mutatja, hogy az NPI-k összkiadása az egész vizsgált időszakban kisebb ingadozásokkal, de növekvő trendet mutat. Az összkiadás a 2000. évi 4,3 Mrd forint körüli értékről 2015-re 22 milliárdot meghaladó értékre emelkedett, ami több mint 5-szörös növekedést jelent. A személyi jellegü kiadások a 2000. évben 1,1 Mrd Ft-ot, 2004-ben 2,6 Mrd Ft-ot és 2015-ben 5,5 Mrd Ft-ot tettek ki. A személyi kiadások értékelését érdemes az előző részben bemutatott létszám-értékelés tükrében megtenni, ugyanis ott láttuk, hogy az alkalmazotti létszám egyre nagyobb arányban tartalmazott közfoglalkoztatottakat, így a nem közfoglalkoztatott munkatársak bérjellegü költségeinek a növekedése kisebb. A dologi kiadások 2000-ben 1,3 Mrd Ft-ot tettek ki, 2004-ben 2,6 Mrd Ft-ot és 2015-ben közel 9 Mrd Ft-ot. Ez az egész vizsgált időszakra nézve 6,7-szeres növekedést, 2004-hez viszonyítva pedig 3,5-szörös növekedést jelent nominális értékben. A beruházási, felhalmozási jellegü kiadások a teljes vizsgált időszak alatt 4,5-szörösére emelkedtek, de 2004-hez képest is 2,2-szeres növekedést mutatnak, s 2015-ben megközelítették a 7,9 Mrd Ft-ot. A felhalmozási jelegü kiadások az időszak közepén még elég ingadozó mértékủek voltak, valószínüsíthetően a nemzetközi forrásokból származó bevételek változó ütemezése miatt. 


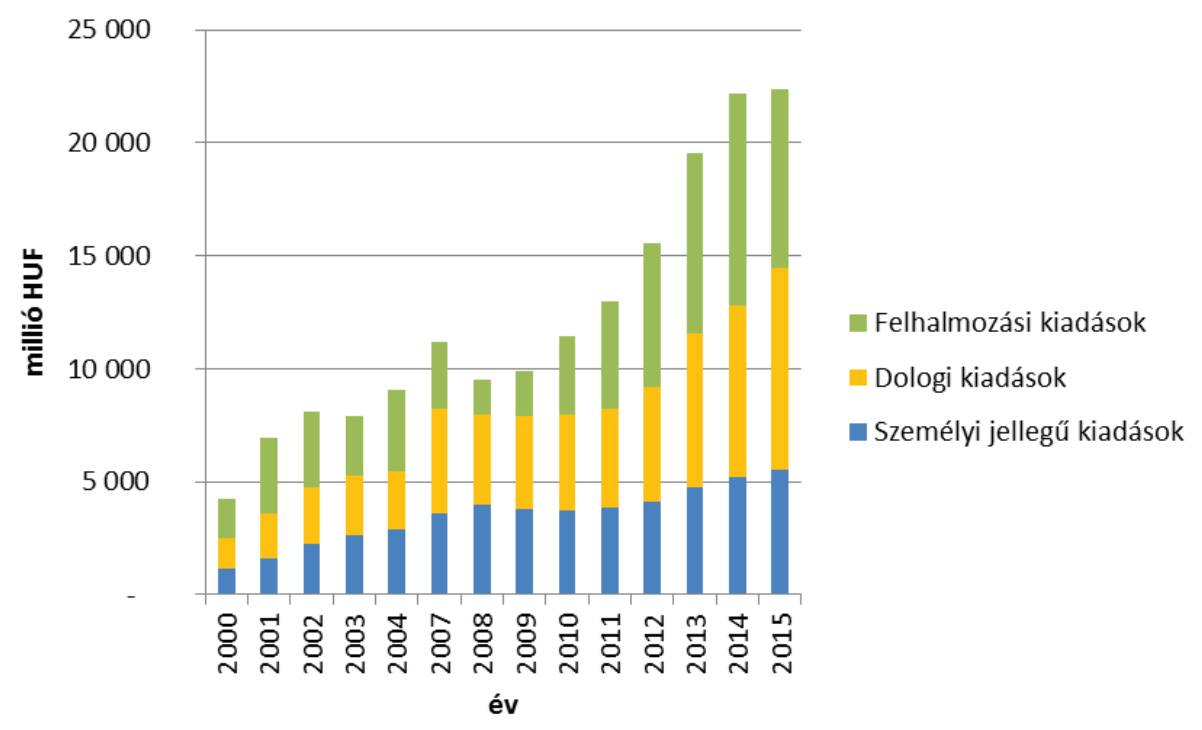

5. ábra. A nemzeti park igazgatóságok megvalósult költségvetése kiadási oldalának változása 2000-2015-ig a fóbb kiadási kategóriák szerinti bontásban (saját szerkesztés a zárszámadási törvényekhez kapcsolódó minisztériumi, fejezeti beszámolók számszaki táblázatai alapján). Megj.

A kiadásokban a kölcsönök nem szerepelnek. A 2005. és 2006. évben a fejezeti (minisztériumi) zárszámadási beszámolók és mellékleteik nem tartalmazták a nemzeti park igazgatósági költségvetés kiadásait, ezért ennek a két évnek az adatai nem szerepelnek az ábrában.

A kiadási oldal áttekintésével láthatjuk, hogy a dologi és beruházási jellegü költségvetés növekedése segítette a megnövekedett feladatok ellátását. A létszámelemzés tükrében a személyi kiadások növekedése azonban bizonyosan nem követte megfelelö ütemben a feladatnövekedést.

A kiadási oldal mellett érdemes megnézni a források összetételét is, hogy lássuk, miből is finanszírozták az igazgatóságok a megnövekedett kiadásaikat. Az NPI-k költségvetésének bevételi oldalát tekintve megkülönböztethetünk közvetlen (állami, költségvetési) támogatást, átvett pénzeszközöket/támogatásértékủ bevételeket és intézményi bevételeket. A közvetlen támogatás a fejezettől (felügyeletet ellátó minisztériumtól) kapott, az év folyamán időarányosan rendelkezésre álló támogatás, amely az alapfeladatok ellátását szolgálja, s müködési és felhalmozási jellegü is lehet a felhasználása alapján. Az intézményi bevételek az NPI-k saját bevételei, amelyeknek egyik része a müködési bevétel (pl. haszonbérleti díjak, értékesített termékek és szolgáltatások ellenértéke, ÁFA visszatérülés), másik része a tőke jellegü bevételek (pl. tárgyi eszközök, immateriális javak értékesítése). Ezt is fordíthatják müködési és felhalmozási célra egyaránt. Az államháztartáson belülről és kívülről átvett pénzeszközök, támogatásértékủ bevételek közé tartoznak a ha- 
zai és nemzetközi pályázatokon elnyert fejlesztési támogatások, agrártámogatások, valamint az egyéb, pl. fejezeti kezelésú elöirányzatból vagy más szervezettől átvett pénzeszközök, támogatásértékü bevételek. Ez utóbbiakat is tovább lehet bontani aszerint, hogy múködési vagy felhalmozási célra kapta azokat az NPI. Tulajdonképpen az átvett pénzeszközök, támogatásértékü bevételek is támogatásokat takarnak a legtöbb esetben, de ezek nagy részére pályáznia kell az igazgatóságoknak, a felhasználásuk részben vagy egészben kötött, s nagyon eltérőek a hozzáférésük, lehívásuk, pénzügyi ütemezésük szabályai is. 2014-től részben támogatásnak is nevezik már őket, de továbbra is meg kell különböztetnünk őket a közvetlen állami támogatásoktól. A 6. ábra a bevételek alakulását a fő források szerinti bontásban mutatja be. A 6 . ábra alapján az igazgatóságok költségvetésé-

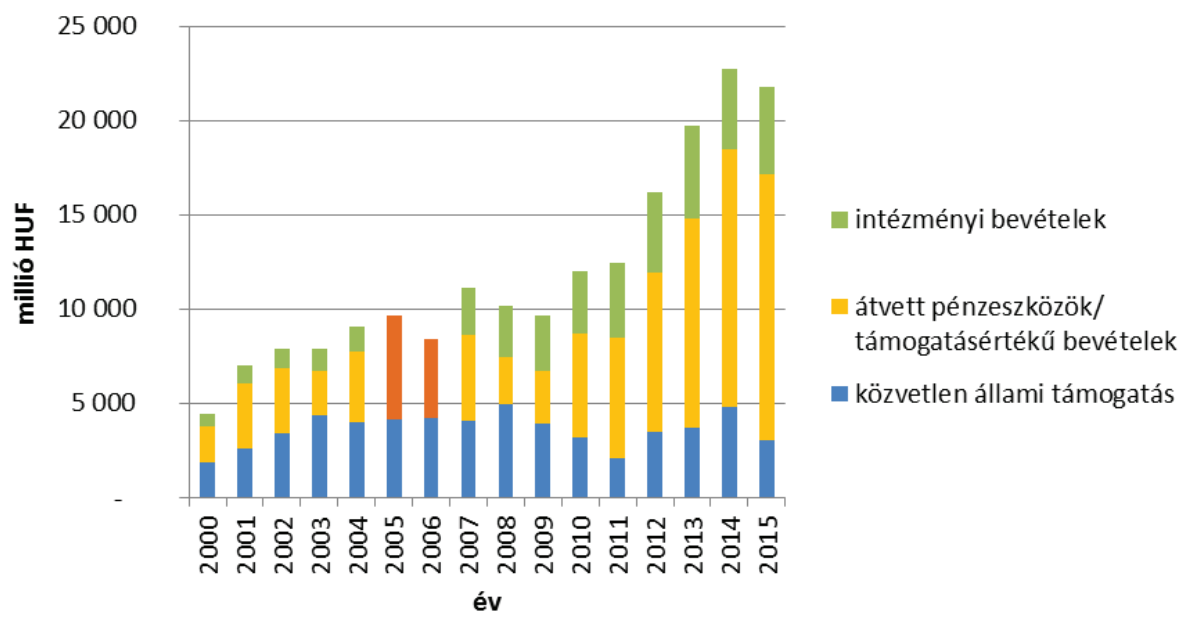

6. ábra. A nemzeti park igazgatóságok megvalósult költségvetése forrás oldalának változása 2000-2015-ig a főbb bevételi kategóriák szerinti bontásban (saját szerkesztés a zárszámadási törvényekhez kapcsolódó minisztériumi fejezetek számszaki táblázatai alapján). Megj. Az összegek nem tartalmazzák az előző évi előirányzat- és pénzmaradvány átvételt. A 2005. és a 2006. évre vonatkozóan nem álltak rendelkezésre adatok a kívánt bontásban, de a közvetlen támogatáson felüli bevételek összevont adatát a 2006. évi fejezeti (minisztériumi) szöveges beszámoló tartalmazta mindkét évre vonatkozóan. Ezt mutatja a narancssárga oszloprész az adott éveknél.

nek forrás oldalát a három fó bevételi típus bontásában megvizsgálva megállapíthatjuk, hogy az NPI-k költségvetésének növekedése (bevétel oldalán ez a ciklus elejéhez képest közel 5-szörös) legnagyobb részben az átvett pénzeszközök, támogatásértékü bevételek növekedésének, kisebb részben az intézményi bevételek növekedésének tudható be. A közvetlen támogatás még nominális értékben sem emelkedett lényegesen a vizsgált időszak alatt, végig $5 \mathrm{Mrd}$ forint alatt maradt. 
2000-ben 1,8 Mrd Ft-ot tett ki, s 2015-ben 3 Mrd Ft körüli értéket mutatott, amivel a 2002-es szintet sem érte el. Az átvett pénzeszközök a 2000-es 1,9 Mrd Ft-ról, 2004-re 3,7 Mrd Ft-ra emelkedtek, s 2015-re meghaladták a 14 Mrd Ft-ot. Ez az időszak elejéhez képest 7,4-szeres, míg az uniós csatlakozás évéhez viszonyítva 3,8-szeres növekedést jelent. Az átvett pénzeszközök növekedése az uniós pályázati források (agrár- és fejlesztési támogatások) megnyílásának volt a leginkább köszönhető. Az intézményi bevételek a vizsgált időszak elejéhez viszonyítva 6,6-szeres növekedést, 2004-hez képest pedig 3,4-szeres növekedést mutattak. 2000-ben még az 1 Mrd Ft-ot sem érték el (0,7 Mrd Ft), 2004-ben 1,4 Mrd Ft-ot, 2015-ben már 4,6 Mrd Ft-ot tettek ki. Meg kell azonban jegyezni, hogy összértékük az egész időszak alatt $5 \mathrm{Mrd} \mathrm{Ft} \mathrm{alatt} \mathrm{maradt.} \mathrm{Az} \mathrm{intézményi} \mathrm{bevételek} \mathrm{növe-}$ kedése valószínüsíthetően az igazgatóságok által nyújtott szolgáltatások bevételeihez (pl. erdei iskolai, ökoturisztikai szolgáltatások, kapcsolódó ajándéktárgyak értékesítése), termények és állatok értékesítéséből származó bevételekhez, ÁFA visszatérülésekhez kapcsolódott, illetve 2014-ig a haszonbérleti díjakból befolyó bevételek növekedésének is volt köszönhető. A haszonbérleti díjakat 2014-től megkötött haszonbérleti szerződésekben $1250 \mathrm{Ft} / \mathrm{AK} / \mathrm{é}_{\mathrm{v}}$ értékben maximálta az igazgatóságok vagyonkezelési tevékenységét szabályozó VM utasítás, s a későbbi években is csak az infláció mértékével engedélyezte az emelést (12/2012. (VI. 8.) VM utasítás). E szabályozás hatására a haszonbérleti díjakból származó bevétel 2014 után valószínüsíthetően csökkent az előző évekhez képest. Az intézményi bevételek összetételének részletesebb elemzéséhez azonban már az igazgatóságok költségvetési beszámolóinak elemzésére lenne szükség.

Az egyes bevételi kategóriák összes bevételen belüli aránya is jelentősen megváltozott a vizsgált időszak alatt. Míg 2000-ben a közvetlen támogatás aránya 41\% volt az összes bevételen belül, addig 2015-ben már csak 14\%. Az átvett pénzeszközök összes bevételen belüli aránya 2000-ben 43\% volt, 2015-ben pedig $65 \%$. Az intézményi bevételek aránya az időszak eleji 16\%-ról az időszak végére $21 \%$-ra emelkedett.

A fenti értékelés alapján megállapíthatjuk, hogy az igazgatóságok alapfeladatainak növekedését nem követte a közvetlen támogatás növekedése, így azt részben külső forrásokból (átvett pénzeszközök és intézményi bevételek) kellett finanszírozniuk. Az intézményi bevételek elérhető nagysága azonban az igazgatóságok alaptevékenységének jellegéből adódóan korlátos volt, amit az is mutat, hogy a növekedés ellenére sem haladta meg az 5 Mrd Ft-ot a vizsgált időszak végén. A haszonbérleti díjakból származó bevételeknek részben a 2014-ben bevezetett szabály, részben a gazdálkodók limitált fizetési képessége, a környezeti nevelési és ökoturisztikai programok és kapcsolódó ajándéktárgy értékesítés bevételének pedig a fő célcsoportok (iskolások, családok) korlátozott fizetési képessége sza- 
bott határt. A termény- és állatértékesítés bevétele is korlátozott lehetett, hiszen ez az alaptevékenység, a természetvédelmi kezelés mellékterméke volt csupán, nem ezek előállítása volt a fő cél. Ez azt jelenti, hogy az igazgatóságok valószínúsíthetően növekvő mértékben építettek az átvett pénzeszközökre, támogatásértékü bevételekre az alapfeladataik finanszírozásánál is.

Mindhárom bevételi kategóriának van müködési és felhalmozási alkategóriája is. Ha ezt a bontást nézzük, akkor tovább árnyalhatjuk a képet aszerint, hogy az intézményi bevételek miből származnak, illetve a közvetlen támogatások és átvett pénzeszközök, támogatásértékü bevételek milyen kiadásokat finanszírozását célozták meg leginkább (7. ábra). Az intézményi bevételek bontásából nem tudunk következtetni a felhasználási oldalra, csak arra, hogy a müködésből adódó bevételek, vagy tőke jellegủek (pl. tárgyi eszközök értékesítéséből származnak). Az átvett pénzeszközöknél, támogatásértékü bevételeknél is csak azt tudjuk meg-

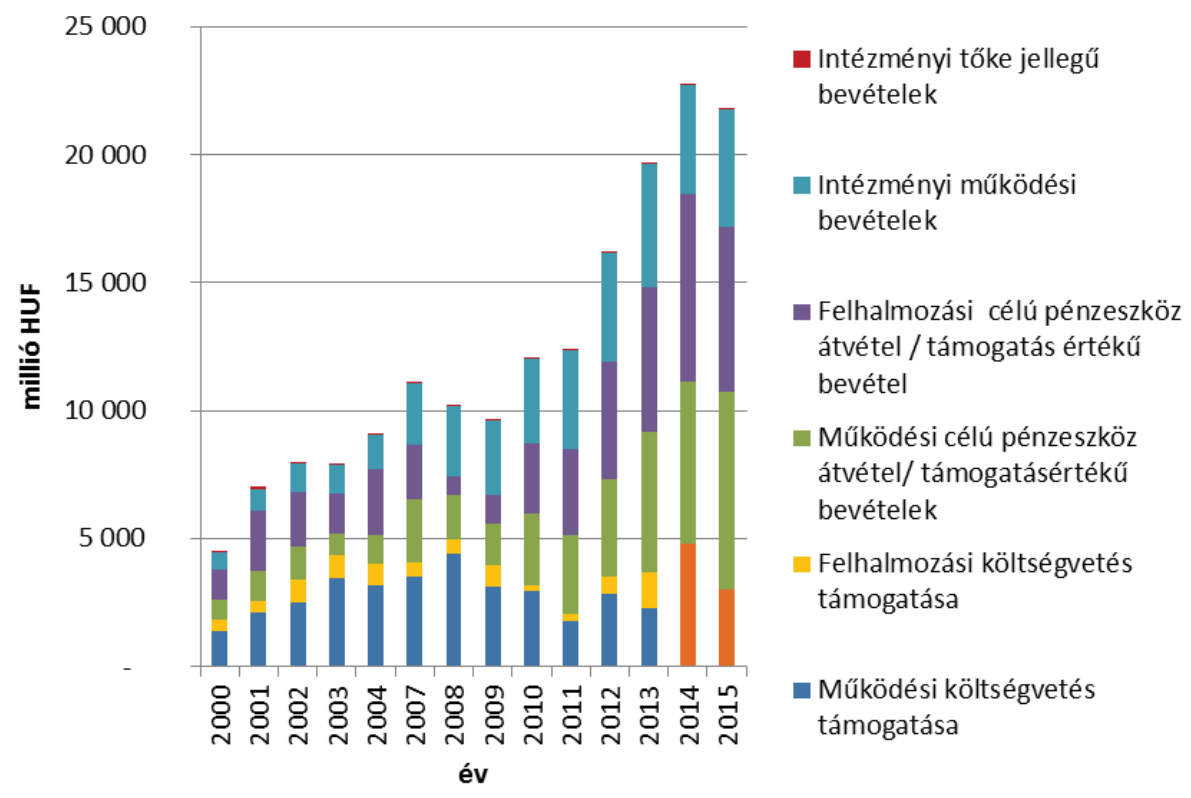

7. ábra. A nemzeti park igazgatóságok megvalósult költségvetése forrás oldalának változása 2000-2015-ig a főbb bevételi kategóriák mủködési és felhalmozási jellegủ alábontása alapján (saját szerkesztés a zárszámadási törvényekhez kapcsolódó minisztériumi fejezetek számszaki táblázatai alapján). Megj. Az összegek a bevételek előző évi maradvánnyal csökkentett összegeit tartalmazzák. A 2005-ös és 2006-os évekre nem állt rendelkezésre ez a részletes bontás a zárszámadási törvényben és kapcsolódó fejezeti (minisztériumi) dokumentumaiban, emiatt ezek az évek nem szerepelnek a diagramban. 2014-től megváltoztak a forrás oldal részletes lebontásának szabályai, és a közvetlen támogatás alábontása megszünt. Emiatt az ábrában is összevontan szerepel a közvetlen támogatás az utolsó két évben, narancssárga színnel jelölve. 
nézni, hogy mire kapták a bevételt, a tényleges felhasználásnál lehettek eltérések átcsoportosítások miatt. Ennek ellenére egy hozzávetőleges képet azért adnak a felhasználás irányáról is. A 7. ábrából egyrészt azt látjuk, hogy a közvetlen támogatás túlnyomó része a müködési kiadások finanszírozását szolgálta a teljes időszak alatt. Másrészt az átvett pénzeszközök változó mértékben célozták meg a müködési és a felhalmozási, beruházási kiadások finanszírozását: 30\%-70\% és 70\%-30\% között ingadozott a két kategória aránya, 2015-ben 45\% volt a felhalmozási célú kategória aránya. Harmadrészt az intézményi bevételek majdnem teljesen egészében müködési bevételek, az időszak végén $1 \%$ körüli érték volt csupán a tőke jellegü bevétel. Ez utóbbi felhasználási céljait a táblázat nem mutatja. A fentiek alapján és a korábbi kiadásokra vonatkozó kimutatásokat alapul véve megállapíthatjuk, hogy a közvetlen állami támogatás nem volt elegendő a müködési (személyi és dologi) kiadások finanszírozására, ahhoz az átvett pénzeszközök, támogatásértékủ bevételek, valamint valószínűsíthetően az intézményi bevételek egy részének igénybevételére is szükség volt.

Az átvett pénzeszközök, támogatásértékü bevételek sokféle forrást foglalnak magukba, a fejezeti kezelésủ előirányzatokból kapott célzott támogatások mellett leginkább hazai és nemzetközi pályázati forrásokat tartalmaznak. Az átvett pénzeszközök egyedi forrás szerinti alábontása a minisztériumi zárszámadási beszámolók alapján nem lehetséges, ahhoz az igazgatósági költségvetési beszámolókra lenne szükség. A fóbb források változását azonban meg tudjuk nevezni az uniós költségvetési ciklusokhoz igazítva (3. táblázat), s kiemelhetünk néhány példát.

Az uniós csatlakozás előtt még a hazai források domináltak az átvett pénzeszközök között, azon belül is a KAC, a Széchenyi pályázat és egyéb fejezeti kezelésủ előirányzatok. Ezek voltak a legfőbb beruházások (köztük ökoturisztikai beruházások) forrásai és a vagyonkezelési tevékenységeket is részben már ezek finanszírozták (Kovács 2005). Emellett már ebben az időszakban is megjelent néhány nemzetközi forrás, mint pl. a GEF vagy a LIFE. A csatlakozás után egyre nagyobb mértékủ lett a nemzetközi, azon belül az uniós források felhasználása, különösen a 2007-2013-as ciklustól kezdve, amely már egy teljes uniós költségvetési ciklus volt.

A vizsgált időszak egészében jelentős uniós forrásnak számított a LIFE, amely már 2000-ben megnyílt az NPI-k számára is, s legföképpen Natura 2000-es fajok és élőhelyek megőrzését támogatta. Mivel a LIFE pályázatok legtöbbször konzorciumok keretében valósulnak meg és csak az össztámogatás, illetve összköltségvetés euróban kifejezett összege áll rendelkezésre központi adatbázisokban, ezért igazgatóságokra lebontott pontos forint összeg csak az igazgatósági költségvetési beszámolók számszaki részéből lenne kinyerhető. Indikációnak annyit meg lehet említeni, hogy 2000-2003 között 3 pályázat nyert NPI részvételével közel 1,8 mil- 
3. táblázat. Az igazgatóságok által igénybevett átvett pénzeszközök, támogatásértékü bevételek kiemelt kategóriái 2000-2015 között uniós költségvetési ciklusonként, hazai és nemzetközi forrás bontásában (a fejezeti zárszámadási beszámolók adatai alapján saját szerkesztés). Megj. A források adott ciklushoz rendelése csak a forrás igénybevételének lehetőségét jelzi, a kifizetések a pályázatok eltérő ütemezése alapján részben áthúzódhattak a következő ciklusra. A 2014-2015-ös időszak az uniós 2014-2020-as költségvetési ciklusának első két éve. A nemzetközi források esetében 2014 és a 2015. évben csak az agrártámogatások egy részénél volt kifizetés, a többi pályázati forrásnál a ciklus későbbi éveire húzódott, húzódik át a pályázás, a szerződéskötés és a kifizetés.

KAC: Környezetvédelmi alap célfeladat fejezeti kezelésű előirányzat

KÖVICE: környezetvédelmi és vízügyi célelőirányzat

ÉTT: érzékeny természeti területek

GEF. Global Environmental Fund (Globális Környezetvédelmi Alap)

PHARE:(Pologne, Hongrie Aide a la Reconstruction économique) európai uniós előcsatlakozási alap

LIFE: (L'Instrument Financier pour l'Environnement) az Európai Unió környezetvédelmi politikáját támogató pénzügyi eszköz

KIOP: Környezet és Infrastruktúra Operatív Program, KEOP: Környezet és Energia Operatív Program, KEHOP: Környezet és Energiahatékonysági Operatív Program Interreg, későbbi ciklusokban ETE (Európai Területi Együttműködés): határon átnyúló, több országot érintő uniós társfinanszírozású támogatási programok

AVOP: Agrár- és Vidékfejlesztési Operatív Program

ROP-ok: regionális operatív programok

VEKOP: Versenyképes Közép-Magyarország Operatív Program

GINOP - Gazdaságfejlesztési és Innovációs Operatív Program

\begin{tabular}{cll}
\hline Időszak & \multicolumn{1}{c}{ kiemelt hazai források } & \multicolumn{1}{c}{ kiemelt nemzetközi források } \\
\hline $2000-2003$ & KAC & GEF, \\
& Széchenyi pályázat & PHARE, \\
& ÉTT támogatás (2002-től) fejezeti & LIFE \\
& kezelésű előirányzatok & \\
\multirow{2}{*}{$2004-2006$} & KÖVICE & uniós agrártámogatások \\
& közmunka támogatás (2005-től) & LIFE \\
& nemzeti agrártámogatások & Interreg \\
& & KIOP \\
& & AVOP \\
$2007-2013$ & KÖVICE & uniós agrártámogatások \\
& közmunka támogatás & LIFE+ \\
& nemzeti agrártámogatások & EU Strukturális alapokból: KEOP, \\
& & ETE, ROP-ok \\
& közfoglalkoztatási támogatás & uniós agrártámogatások \\
& nemzeti agrártámogatások & LIFE EU Strukturális és kohéziós \\
& & alapokból: KEHOP, VEKOP, GI- \\
& & NOP, ETE \\
\hline
\end{tabular}

lió euró uniós támogatással, 2004-2006 között már 10 pályázat volt eredményes 9,6 millió euró támogatással és 2007-2013 között 18 nyertes pályázat volt 38,8 millió euró támogatással (http4 alapján saját számítás). 
Az EU strukturális alapjaiból is egyre növekvő forrást tudtak az igazgatóságok igénybe venni a vizsgált időszakban, amelyet az NPI-k ki is használtak. Pontos adatok központi adatbázisban csak a magyarországi tervezésü programokra álltak rendelkezésre. Ezek között a legnagyobb tételt a környezetvédelmi célú operatív programok (KIOP, KEOP, illetve a regionális operatív programok képviselték (4. táblázat). Az uniós csatlakozás óta jelentős tételt képviselnek az igazgatóság

4. táblázat. A nemzeti park igazgatóságok által igénybe vett ERFA (Európai Regionális Fejlesztési Alap) társfinanszírozású támogatások 2004 és 2013 között az uniós költségvetési ciklusok szerinti bontásban (a http5 honlapról lehívott adatok alapján saját számítás).

\begin{tabular}{|c|c|c|c|}
\hline \multirow{2}{*}{ Források } & \multicolumn{2}{|c|}{ Támogatás (millió Ft) } & \multirow{2}{*}{ Finanszírozott tevékenységek fö típusai } \\
\hline & 2004-2006 & $2007-2013$ & \\
\hline KIOP, KEOP & 3277 & 28996 & $\begin{array}{l}\text { élőhelyrekonstrukciók } \\
\text { erdei iskola fejlesztése }\end{array}$ \\
\hline regionális OP-k & 1229 & 9054 & $\begin{array}{l}\text { KMOP: élőhelyrekonstrukciók, erdei } \\
\text { iskola fejlesztések } \\
\text { összes ROP: ökoturisztikai } \\
\text { beruházások }\end{array}$ \\
\hline Összesen & 4506 & 38050 & \\
\hline
\end{tabular}

költségvetésében az uniós agrártámogatások és kapcsolódó nemzeti támogatások. Az NPI-k az Európai Mezőgazdasági Vidékfejlesztési Alapból (EMVA) és a 2. tengelyhez kapcsolódó kísérő intézkedések alapján is részesültek támogatásban, illetve a mezögazdasági tevékenységet segítő közvetlen támogatásokat ${ }^{3}$ is kaptak. Az 5. táblázatban a legfontosabb jogcímcsoportokhoz tartozó támogatásokat láthatjuk. Az EMVA 2 tengelyéből az agrár-környezetgazdálkodási és erdő-környezetvédelmi intézkedések, valamint az őshonos állatok tartásának támogatása jogcímek domináltak, a 3. tengelyből pedig a Natura 2000 területek fenntartási terveihez igényeltek az NPI-k támogatást. A kísérő intézkedések agrár-környezetgazdálkodáshoz és a kedvezőtlen adottságú területek támogatásához kapcsolódtak, míg a közvetlen támogatások a területalapú támogatások mellett a legnagyobb mértékben az állattartást segítő támogatástípusokat tartalmazták. Az 5. táblázatból láthatjuk, hogy az igénybevett agrártámogatások összege a 2005. évi $1 \mathrm{Mrd}$ Ft alatti összegről, az időszak végére már $3 \mathrm{Mrd}$ Ft körüli értékre nőtt. Az agrártámogatások legnagyobb részét a közvetlen támogatások tették ki, de a 2. tengelyes támogatások a kísérő intézkedésekkel együtt is jelentős tételt képviseltek. Ezek alapján megállapíthatjuk, hogy az agrártámogatások a saját vagyon-

3: Ez nem tévesztendő össze a korábban tárgyalt közvetlen állami támogatással, a közvetlen agrártámogatások átvett pénzeszközök, támogatásértékü bevételek. 
kezelésben és saját használatban lévő területek kezeléséhez kapcsolódó feladatok finanszírozásához jelentős mértékben járultak hozzá. 2014-ben változott az egységes területalapú támogatások igénybevételének szabálya, s 150 ezer euró éves egységes területalapú támogatás felett 5\%, 1200 hektárnak megfelelő összeg felett $100 \%$ támogatáscsökkentést írtak elő az érintett mezőgazdasági termelőknél (1437/2014. (VII. 31.) Korm. határozat). Ez az intézkedés erőteljesen érintette az NPI-ket is, csökkentve ezzel a következő években igénybe vehető agrártámogatások összegét.

5. táblázat. A nemzeti park igazgatóságok által 2005 és 2015 között igénybevett agrártámogatások (millió HUF) intézkedéstípusonként (Magyar Államkincstár 2017. márciusi adatszolgáltatása alapján saját számítás). Megj: Az összesítő cellákban tapasztalt kisebb eltérések a kerekítésekből adódnak.

\begin{tabular}{|c|c|c|c|c|c|}
\hline Évek & $\begin{array}{c}\text { EMVA 2: } \\
\text { Környezetvédelmi } \\
\text { intézkedések }\end{array}$ & $\begin{array}{l}\text { EMVA 3: } \\
\text { Vidékfejleszté- } \\
\text { si intézkedések }\end{array}$ & $\begin{array}{c}\text { Kísérő intéz- } \\
\text { kedések }\end{array}$ & $\begin{array}{l}\text { Közvetlen } \\
\text { támogatás }\end{array}$ & Összesen \\
\hline 2005 & & & 260 & 576 & 836 \\
\hline 2006 & & & 221 & 463 & 684 \\
\hline 2007 & & & 69 & 414 & 482 \\
\hline 2008 & & & 281 & 981 & 1262 \\
\hline 2009 & & & 341 & 1431 & 1772 \\
\hline 2010 & & & 299 & 1674 & 1972 \\
\hline 2011 & 360 & & -1 & 1163 & 1522 \\
\hline 2012 & 926 & & & 1749 & 2674 \\
\hline 2013 & 613 & & & 2381 & 2994 \\
\hline 2014 & 1020 & 71 & -3 & 2297 & 3386 \\
\hline 2015 & 714 & 388 & & 1872 & 2974 \\
\hline Összesen* & 3632 & 459 & 1468 & 15001 & 20559 \\
\hline
\end{tabular}

\section{Értékelés}

Az NPI-k feladatkörének és a feladatok mennyiségi mutatóinak áttekintésével megállapíthatjuk, hogy az ellátandó feladatok mind típusaikban, mind mennyiségi szempontból növekedtek 2000 és 2015 között. A legjelenősebb változást az uniós csatlakozás jelentette, amikor ugyan a hatósági jogkör legnagyobb része elkerült az igazgatóságoktól, de ezzel párhuzamosan megjelentek a Natura 2000 területekkel kapcsolatos feladatok. A Natura 2000 területek kijelölésével több, mint 1 millió hektárral növekedett a természetvédelmi kezeléssel érintett területek kiterjedése. A hatóságot segítő funkció is megmaradt, hiszen az igazgatósági szakem- 
berek, kiemelten a természetvédelmi őrök, területi ismereteire továbbra szükség volt a hatósági eljárásokban. A vizsgált időszakban szintén erősödött az igazgatóságok vagyonkezelési, ökoturisztikai és környezeti nevelési funkciója, ami a saját vagyonkezelésben és hasznosításban lévő területek és állatállomány, valamint az oktatási-turisztikai infrastruktúra bővülése mutat.

A feladatok növekedését azonban nem követte a nem közfoglalkoztatott létszám megfelelő arányú növekedése, ezért a hiányzó létszám egy részét az NPI-k valószínüsíthetően egyre inkább a közfoglalkoztatási programból finanszírozott közfoglalkoztatotakkal oldották meg. Ez nem tekinthető kedvező trendnek. A közfoglalkoztatási program ugyan bővíti a természetvédelemben dolgozók körét és átmeneti lehetőséget teremt a munkanélküliek számára, de jelentős többletmunkát jelent az NPI-knek, és csak időszakos munkát biztosít, ezért nem ad foglalkoztatási biztonságot a résztvevők számára sem. A nem közfoglalkoztatott létszámon belül a természetvédelmi őrök létszáma szintén alig növekedett a vizsgált időszak alatt, pedig a Natura 2000 területek kijelölése és az örszolgálathoz rendelt régészeti feladatok ezt indokolták volna. A IV. Nemzeti Természetvédelmi Alapterv (NTA) (2015) is kiemeli a természetvédelmi őrszolgálat létszámbővítésének szükségességét. Az NTA a létszám megduplázását javasolja, amivel 4000 ha körüli értékre tudna csökkenni az egy ör által felügyelt terület. Mihók és munkatársai (2017) is hangsúlyozzák annak fontosságát, hogy a megnövekedett természetvédelmi feladatok ellátására megfelelően finanszírozott szakember állomány álljon rendelkezésre.

A növekvő alapfeladatokkal járó költségek fedezetét a vizsgált időszak alatt az igazgatóságok valószínűsíthetően csak részben tudták előteremteni. A nem közfoglalkoztatott munkatársak létszámának a szükségesnél kisebb mértékủ növekedése és azon belül a természetvédelmi örök folyamatosan alacsony létszáma mindenképpen ezt támasztja alá. Az összköltségvetés ugyan jelentősen növekedett, 2015-ben mind a kiadási mind a bevételi oldalt tekintve 22 Mrd Ft körüli értéket mutatott, de a közvetlen állami támogatás mértéke a vizsgált időszakban végig évi 5 Mrd Ft alatt, s 2015-ben nem érte el nominális értékben a 2002-es szintet. Az intézményi bevételek nőttek a vizsgált időszak alatt, de nagyságrendjükben jóval elmaradtak az átvett pénzeszközöktöl, s 2015-ben sem érték el az 5 Mrd Ft-ot. Növelésükre az NPI-k alapfeladatainak jellege miatt a későbbiekben is csak korlátozottan lesz lehetőség, $\mathrm{s}$ beérkezésük éven belüli ingadozása nem mindig kedvező a likviditás szempontjából. Az NPI-k költségvetésében egyre jelentősebb arányt képviseltek az átvett pénzeszközök, támogatásértékủ bevételek, 2015-ben már elérték a 65\%-ot, s meghaladták a $14 \mathrm{Mrd}$ Ft-ot. Ezek nagy része célzott támogatás volt, amely meghatározott feladatok ellátásra adott csak lehetőséget. Így valószínúsíthető, hogy még növekvő érték esetén sem volt meg a pénzügyi fede- 
zet minden alapfeladat ellátására. Az uniós társfinanszírozású pályázati források bővültek leginkább a vizsgált időszak alatt, ezen belül is az agrártámogatások, az élőhely- és fajmegőrzési, valamint az ökoturisztikai és környezeti nevelést szolgáló infrastruktúra-fejlesztési pályázatok. A kezelési feladatok ellátását az NPI-k vagyonkezelésében lévő saját hasznosítású területeken az agrártámogatások segítették leginkább, de a területalapú támogatások igénybevételének korlátozására 2014-ben hozott szabály kedvezőtlen trendet jelez. Az élőhelyek és fajok védelmét szolgáló pályázatok segítették a természetmegőrzési feladatok ellátását. E pályázatok nagy része ugyanakkor beruházási jellegü volt, így csak korlátozottan, a projekt szűk céljaihoz igazítva, a projekt ideje alatt adtak általában lehetőséget kezelési, kutatási és monitorozási tevékenységek végzésére. Ez azt jelenti, hogy a projektekkel nem érintett területeken a kutatási és monitorozási tevékenységek valószínüsíthetően csak korlátozottan tudtak megvalósulni, vagy egyes esetekben elmaradtak. Egyes uniós pályázatok lehetőséget adtak a létszám bővítésére is, de leginkább csak a pályázathoz kapcsolódó, határozott idejü munkalehetőséget biztosítottak. Így a korábban jelzett nem közfoglalkoztatott létszám egy része sem jelentett hosszú távú foglalkoztatást. Egyes élőhelyrekonstrukciós és fajvédelmi pályázatok (pl. LIFE) előírták a projekt eredményeinek 5 évig való fenntartását, amelyre más forrásból kellett biztosítani a fedezetet. A turisztikai és környezeti nevelést szolgáló infrastruktúra fejlesztése is a legtöbb esetben pályázati forrásokból valósult meg. Ezek a pályázatok egyrészt hozzájárultak ahhoz, hogy az igazgatóságok egyre magasabb színvonalon tudják végezni a kapcsolódó feladataikat, másrészt a működtetést és az állagmegőrzést már nem finanszírozták, így arra az igazgatóságoknak szintén más forrásokból (pl. saját intézményi bevételből) kellett előteremteniük a pénzügyi fedezetet. A pályázati források köre és hozzáférési lehetőségei uniós ciklusonként részben változtak, amely erős bizonytalansági tényezőt jelentett a finanszírozásban, s esetenként likviditási problémákat is okozhatott. Összességében véve a külső pályázati források egyrészt lehetőséget teremtettek a fejlesztésre, de egyben kiszolgáltatottá is tették az igazgatóságokat ezeknek a forrásoknak, s az alapfeladatok folyamatos ellátását is valószínűsíthetően csak részben voltak képesek finanszírozni.

\section{Javaslataim a fenti értékelés alapján a következök:}

Az NPI-k megnövekedett alapfeladataihoz mérten elengedhetetlen a stabil foglalkoztatású szakmai állomány, ezen belül a természetvédelmi őri létszám növelése.

Fontos lenne az NPI-k alapfeladataihoz kapcsolódó éves finanszírozási igény pontos meghatározása és a forráshiányos területek beazonosítása.

Az igazgatóságok stabil, kiszámítható, hosszú távon fenntartható müködéséhez a közvetlen állami támogatás növelése szükséges, amely az alapfeladatok - je- 
lenleginél sokkal nagyobb arányú - finanszírozását biztosítja, s az igazgatóságok külső forrásoknak való kitettségét csökkenti.

\section{További kutatások szükségesek az alábbi területeken:}

A cikk az időszak egészére vonatkozó általános trendeket vette figyelembe, az évenkénti ingadozások vizsgálatára további elemzések szükségesek.

A cikk a fejezeti (minisztériumi) zárszámadási beszámolókból, központi adatbázisokból hozzáférhető s lekérhető adatokon alapult. Részletesebb elemzés készíthető az igazgatóságok számszaki és szöveges beszámolói alapján, mely megmutatja az igazgatóságok közötti különbségeket is.

Igazgatósági és minisztériumi szakértőkkel készített interjúk tovább árnyalhatják az elemzést, pl. a finanszírozási igény és a tényleges források tekintetében.

Köszönetnyilvánitás - Hálás vagyok a kéziratot véleményező volt kollégáimnak, Balczó Bertalannak, Bokros Katalinnak, Kalán Józsefnének, Jakál Lászlónénak, Jósvári Máriának, Pergéné Szilágyi Zsuzsánnának, Szentgyörgyi Péternek és Vajna Tamásnénak, hogy észrevételeikkel, javaslataikkal segítették a kézirat jobbítását, pontosítását. Köszönöm a Földművelésügyi Minisztérium Nemzeti Parki és Tájvédelmi Főosztályának és a Magyar Államkincstárnak, hogy a rendelkezésemre bocsátotta a kért adatokat. Köszönetemet szeretném kifejezni a bírálóknak is a cikk jobbítására tett javaslataikért.

\section{Irodalomjegyzék}

Kovács, E. (2005): A természetvédelem finanszírozása, Változások az elmúlt évek során. Környezetvédelem 13:12-13.

KvVM TKSZÁT - Környezetvédelmi és Vízügyi Minisztérium Természet- és Környezetmegőrzési Szakállamtitkárság (2007): Természetvédelmi Adatok a 2006. december 31-i állapot szerint. Budapest, 52 p.

Mihók, B., Biró, M., Molnár, Zs., Kovács, E., Erős, T., Standovár, T., Török, P., Csorba, G., Bölöni, J., Margóczi, K. \& Báldi, A. (2017): Biodiversity on the waves of history: Conservation in a changing social and institutional environment in Hungary, a post-soviet EU member state. - Biol. Conserv. 211: 67-75. doi: http://dx.doi.org/10.1016/j.biocon.2017.05.005

Országos ökoturizmus fejlesztési stratégia (2008): Pannon Egyetem Turizmus Tanszék, Aquaprofit Zrt., Veszprém-Budapest,

Nemzeti Természetvédelmi Alapterv IV (2015) (kihirdetve a 2015-2020 közötti időszakra szóló Nemzeti Környezetvédelmi Programról szóló 27/2015. (VI. 17.) OGY határozat mellékleteként)

VM TKSZÁT - Vidékfejlesztési Minisztérium Természet- és Környezetmegőrzési Szakállamtitkárság (2012): Természetvédelmi Adatok a 2011. december 31-i állapot szerint. - Budapest, 57 p.

Hivatkozott jogszabályok:

1996. évi LIII. törvény a természet védelméröl 
211/1997. (XI. 26.) Korm. rendelet a környezetvédelmi felügyelőségek, valamint a nemzeti park igazgatóságok feladat- és hatásköréröl, továbbá a Környezet- és Természetvédelmi Főfelügyelöségröl

30/2001. (XII. 28.) KöM rendelet a természetvédelmi kezelési tervek készítésére, készítöjére és tartalmára vonatkozó szabályokról szóló

2/2002. (I. 23.) KöM-FVM együttes rendelet az érzékeny természeti területekre vonatkozó szabályokról

341/2004. (XII. 22.) Korm. rendelet az Országos Környezetvédelmi, Természetvédelmi és Vízügyi Főfelügyelőség, az Országos Környezetvédelmi, Természetvédelmi és Vízügyi Főigazgatóság és a környezetvédelmi és vízügyi miniszter irányítása alá tartozó területi szervek feladat- és hatásköréről

12/2012. (VI. 8.) VM rendelet, a nemzeti park igazgatóságok természetvédelmi célú vagyonkezelési tevékenységének egységes szakmai alapelvek szerinti ellátásáról utasítás (17/2013. (VIII. 1.) VM utasítással módosított)

A vidékfejlesztési miniszter NPTF-172/4/2012 utasítása a Nemzeti Parki Termék védjegy használatáról

1437/2014. (VII. 31.) Korm. határozat az egységes területalapú támogatás összegéhez kötött támogatás felső szintjének megállapításáról és a mezőgazdasági munkahelyteremtés elősegítéséről

71/2015. (III. 30.) Korm. rendelet a környezetvédelmi és természetvédelmi hatósági és igazgatási feladatokat ellátó szervek kijelöléséről

\section{Az elemzéshez felhasznált zárszámadási törvények és mellékleteik:}

2001. évi LXXV. törvény a Magyar Köztársaság 2000. évi költségvetésének végrehajtásáról

2002. évi XL. törvény A Magyar Köztársaság 2001. és 2002. évi költségvetésének 2001. évi végrehajtásáról

2003. évi XCV. törvény a Magyar Köztársaság 2001. és 2002. évi költségvetésének 2002. évi végrehajtásáról

2004. évi C. törvény a Magyar Köztársaság 2003. évi költségvetésének végrehajtásáról

2005. évi CXVIII. törvény a Magyar Köztársaság 2004. évi költségvetéséről és az államháztartás hároméves kereteiről szóló törvény végrehajtásáról

2006. évi XCIX. törvény a Magyar Köztársaság 2005. évi költségvetésének végrehajtásáról 2007. évi CXXVIII. törvény a Magyar Köztársaság 2006. évi költségvetésének végrehajtásáról 2008. évi LXXVIII. törvény a Magyar Köztársaság 2007. évi költségvetésének végrehajtásáról 2009. évi CXXIX. törvény a Magyar Köztársaság 2008. évi költségvetésének végrehajtásáról 2010. évi XCVIII. törvény a Magyar Köztársaság 2009. évi költségvetésének végrehajtásáról 2011. évi CXXXIII. törvény a Magyar Köztársaság 2010. évi költségvetésének végrehajtásáról

2012. évi CLV. törvény a Magyar Köztársaság 2011. évi költségvetéséről szóló 2010. évi CLXIX. törvény végrehajtásáról

2013. évi CXCIII. törvény a Magyarország 2012. évi központi költségvetéséről szóló 2011. évi CLXXXVIII. törvény végrehajtásáról

2014. évi LXII. törvény a Magyarország 2013. évi központi költségvetéséről szóló 2012. évi CCIV. törvény végrehajtásáról

2015. évi CLXXII. törvény a Magyarország 2014. évi központi költségvetéséről szóló 2013. évi CCXXX. törvény végrehajtásáról

2016. évi CXXII. törvény a Magyarország 2015. évi központi költségvetéséröl szóló 2014. évi C. törvény végrehajtásáról 


\title{
Internetes hivatkozások:
}

http1: Költségvetési Felelősségi Intézet honlapjának alpontja, melyről link mutat minden év zárszámadási törvényéhez kapcsolódóan benyújtott fejezeti számszaki és szöveges dokumentumokhoz: http://kfib.hu/hu/torvenyek-zarszamadasok (letöltés: 2017. február).

http2: KSH fogyasztói árindex adatai 1985-töl: https://www.ksh.hu/docs/hun/xstadat/xstadat eves/i qsf001.html (letöltés, 2017 május)

http3: A hazai természetvédelem hivatalos honlapjának alpontja, melyről „korábbi évek adatai” címszó alatt lehívható az országos jelentőségü, egyedi jogszabállyal védett természeti területek listája a vizsgált évekre vonatkozóan: http://www.termeszetvedelem.hu/orszagos-jelentosegu-egyedijogszaballyal-vedett-termeszeti-teruletek (letöltés: 2017. február)

http4: Nyertes természetvédelmi LIFE pályázatok adatai 2000-2014 között: http://www.termeszetvedelem.hu/_user/browser/File/LIFE/M\%C3\%A1solat\%20eredetijeLIFE_LIFE+ Nature palyazatok adatai 2000-2014\%281\%29.pdf (letöltés: 2017. február)

http5: projektkereső Magyarország Kormányának pályázati honlapján, mellyel a megadott szűkítési szempontokkal pályázatok főbb adatai listázhatók: https://www.palyazat.gov.hu/tamogatott projektkereso (letöltés: 2017. március)

\section{Assessment of the Hungarian national park directorates' budget between 2000 and 2015 in the light of their main tasks}

\author{
Eszter Kovács \\ Szent István University, Institute of Nature Conservation and Landscape Management, \\ H-2100, Gödöllö, Páter Károly u. 1, Hungary \\ e-mail:kovacs.eszter@mkk.szie.hu
}

The continuous availability of sufficient amount of financial sources for fulfilling the main tasks of the national park directorates (NPDs) is vital for their stable operation. In this paper the changes in the tasks of NPDs between 2000 and 2015 are assessed, and compared to the changes in the number of personnel and the available financial sources. Based on the results it can be stated that in the examined period, and especially after the accession to the EU, the scope of tasks of the NPDs broadened and the workload increased. The number of personnel grew as well, but it was mostly due to the increase in the number of public service employees, while the number of other employees including the national park rangers increased only slightly in the examined period. The budget of the NPDs also had grown, it was almost 5 times higher at the end of the period compared to the year of 2000, but it was mostly due to the increase in the external sources, especially funding coming from the European Union. At the same time the direct state support did not grow significantly, in 2015 it did not even reach the nominal level of 2002. This increased the dependence of the NPDs on the external financial sources, the majority of which was strictly regulated and earmarked. It means that underfinanced tasks could have remained even in the case of the increased revenues. Based on the results the assessment of the financial needs related to the main tasks is recommended as well as increasing the direct state support and the number of stable, non public service personnel. The analysis can be deepened by further research and the results can be assessed in the international context.

Keywords: national park directorates, budget, financing, national and international financial sources 